\title{
TITLE: Empathy in pregnant women and new mothers: A systematic literature review
}

\author{
Abstract \\ Objective: This systematic review identifies literature that explores changes in \\ empathy in the perinatal period and the influence of empathy fluctuations on \\ maternal behaviours and child development.
}

Background: The wellbeing and development of infants are commonly regarded as linked to their mothers' capacity for empathy. However, characteristic changes during pregnancy and childbirth including sleep deprivation, mood, and cognitive difficulties may disrupt empathic processing.

Methods: Original research papers $(n=7413)$ published in English language peerreviewed academic journals were obtained by searching four electronic databases PsycINFO, PubMed, Scopus, and CINAHL. Inclusion criteria were studies reporting empathy of women in the period from pregnancy to twelve months postpartum. Empathy was operationalised as a general tendency of empathic emotional responding and cognitive perspective taking. Thirteen studies meeting the inclusion criteria were systematically assessed for quality of topic clarity, operational definitions, methodology, and data analysis using the Critical Appraisal Skills Programme (CASP) criteria.

Results: Impaired empathy in mothers, due most notably to high personal distress, was associated with risk of neglect or maltreatment of children and was partially explained by mothers' aversive response to infant crying. Available data enabling the evaluation of fluctuations in empathy capacity remains inadequate.

Conclusion: Few studies present empathy as a central theme within the research, there is a paucity of definitional parameters and theoretical linkages, and overreliance on brief self-report indices of empathy. Future theory-grounded studies that incorporate an experimental approach with greater sampling diversity are needed to broaden and advance our understanding of empathy in perinatal women.

Keywords: empathy; pregnancy; motherhood; life transition; maternal behaviour; personal distress 


\section{Introduction}

Empathy is the capacity to understand and share the affective experience of others (Decety and Jackson, 2004) and is instrumental in successful communication and caring interpersonal relationships (Batson, 2011; de Waal, 2009). Infant cues associated with hunger or discomfort evoke an emotional reaction which motivates caregiving (Swain et al., 2014). This emotional response is commonly attributed to empathy (Zeifman, 2003). Extremes of emotional response are believed to be a risk factor in poor mother-child bonding and child maltreatment or neglect (de Paúl, Pérez-Albéniz, Guibert, Asla, \& Ormaechea, 2008).

Empathic parents are more likely to have securely attached children than lowempathy parents (Stern, Borelli, \& Smiley, 2015). A child who experiences consistent, responsive caregiving in infancy feels secure in their relationship with their caregiver (Ainsworth, 1979). Relational security during infancy provides a foundation for successful social interactions in later life (Ranson, 2008). Higher levels of empathy in mothers were associated with the development of empathy and prosocial behaviours in their five-year-old children (Farrant, Devine, Maybery, \& Fletcher, 2012).

Given the putative benefits of empathy, relatively little is known about whether mothers have an inherent ability to be empathetic, are simply motivated to develop empathy, or inevitably develop adaptive psychological maternal qualities as a result of pregnancy and childbirth. Women self-report heightened empathy following childbirth (Hodges, Kiel, Kramer, Veach, \& Villanueva, 2010) but there is little empirical evidence supporting this claim. Oxytocin appears to be a plausible candidate for explaining this change, with oxytocin thought to trigger increases in empathy (Rocchetti 
et al., 2014) and facilitate prosocial behaviour, affiliation, trust and social cognition (Heinrichs, von Dawans, \& Domes, 2009; Shamay-Tsoory and Abu-Akel, 2016).

However, empathy may impose substantial demands on cognitive processing. Reduced cognitive control is believed to contribute to the empathic difficulties that emerge both developmentally (Schwenck et al., 2014) and in the context of clinical illness (Shamay-Tsoory, 2011). Cognitive deficits are apparent during periods of stress (Shansky and Lipps, 2013) as well as pregnancy and postpartum (Davies, Lum, Skouteris, Byrne, \& Hayden, 2018). Brain scans of pre- and post-pregnancy women showed reductions in gray matter volume in brain regions associated with social processing indicated pregnancy-related long-term neural adaptations (Hoekzema et al., 2017). Furthermore, sleep deprivation (Reynolds and Banks, 2010) and mood disorders (Gohier et al., 2009) have a detrimental impact on cognitive processing and consequently may reduce a mother's capacity for empathy.

Mothers with mild to moderate depression show impaired empathic processing, reduced emotional responsiveness, more negative than positive affect expression, and less emotional mirroring in their interactions with their infant (Reck et al., 2004). Mirroring and emotional expressiveness contribute to, and communicate, empathic understanding (Preston \& de Waal, 2002; Sonnby-Borgström, Jönsson, \& Svensson, 2003). Lack of empathy and emotional availability in depressed mothers can, in turn, inhibit development of healthy mother-child bonds (Huang, Lewin, Mitchell, \& Zhang, 2012; Martins \& Gaffan, 2000) and impede children's emotional development (DeKlyen \& Greenberg, 2008; Tharner et al., 2012). This has implications for the children of mothers with postnatal depression.

\section{Rationale for this review}

Despite the apparent importance of empathy in sensitive caregiving (Stern, et al., 2015), 
an overview of research investigating empathy in women during the perinatal period is lacking. The transitional period of pregnancy and motherhood represents a significant life disruption and often involves significant mental, physical, financial, and social adjustments capable of generating elevated levels of stress (Aber, Weiss, \& Fawcett, 2013).

The relative position of motherhood as a major life stressor is recognised in the classic work in the field: the studies emanating from the development of the Social Readjustment Rating Scale (SRRS) by Holmes and Rahe (1967). According to this work, pregnancy was ranked at 40 on a scale of 100 . In fact, the birth of a child represents a life interruption and social readjustment that may well exceed the death of a spouse as it conflates a number of categories of adjustment such as "gain of a new family member" (39 points), "sex difficulties" (39 points) and "change in financial state" (38 points). The perinatal period is associated with increased strain on the cognitive and psychological resources of perinatal women which in turn are linked to empathy, and the implications may extend beyond the context of the mother to infant relationship.

This systematic review of current research focuses on changes or disruptions to the psychological process of empathy in pregnant and postpartum women and associated consequences. The following questions formed the basis of the review: How has empathy been conceptualised and measured? Is empathy enhanced or impaired during pregnancy or early motherhood? What are the consequences of empathy on mothering behaviours, child development, and mothers' psychological wellbeing? 


\section{Methods}

\section{Sources and study selection}

Original research papers published in English language peer-reviewed academic journals were obtained by searching electronic databases from across several disciplines to cover the interdisciplinary nature of the topic: PsycINFO, PubMed, Scopus, and CINAHL. No publication date restrictions were imposed, and the last search was conducted on 8 September 2017. Works published subsequently were considered for inclusion. Articles were retrieved using the following search string: ["empath*"] AND ["Pregnan* OR Antenatal OR Perinatal OR Birth OR Birth-related OR Child-bearing OR Childbearing OR Postnatal OR Postpartum OR Mother* OR Maternal OR parent*].

Inclusion criteria were studies reporting empathy of women in the period from pregnancy to twelve months postpartum. Empathy was operationalised as a general tendency of empathic emotional responding and cognitive perspective taking. Studies pertaining to empathy embodied within the mother-child relationship were excluded. The Preferred Reporting Items for Systematic Reviews and Meta-Analyses (PRISMA: http://www.prisma-statement.org/) model (Liberati et al., 2009) were used to inform the process. Electronic searching yielded 7413 records of which 13 were retained after duplicates removed and inclusion criteria applied. Figure 1 displays the selection process at each stage of the study.

\section{Analysis and quality assessment}

The systematic quantitative assessment technique outlined by Pickering and Byrne (2014) was followed. The literature is mapped into comprehensive categories and subcategories to enable rigorous assessment. A meta-analysis was not feasible because of several factors. Meta-analyses tend to be used in the analysis of randomised 
controlled trials, each of which offer high quality evidence. In order to be reconciled in a single study, each trial included in a meta-analysis needs to have similar measures reported in sufficient detail to be standardised (Deeks, et al., 2008). This review includes studies that measure empathy as a general capacity rather than within the mother-child relationship (maternal empathy). The decision to exclude maternal empathy research is based on a lack of conceptual clarity and use of customised measures which overlap with other qualities of the mother-child relationship such as maternal sensitivity, responsivity, mind-mindedness, insightfulness, and maternal warmth (Stern, et al., 2015).

The quality of the 13 articles was guided by the Critical Appraisal Skills Programme (CASP: http://www.casp-uk.net) criteria for cross-sectional and longitudinal trial studies. The CASP tool assesses risk of bias in quantitative research according to topic clarity, research design, sampling, measurement, and data analysis. Aligning with the review focus, the quality assessment also evaluated content directly pertaining to empathy: operational definition, measurement, generalisation, validity of results, and reliability. Assessment criteria were scored as 0 (= not met) or 1 (= met). Most of the studies did not seek to investigate the dimensions of empathy in mothers but instead included empathy as a characteristic or trait which may influence the primary construct of interest, such as response to infant cries. Consequently, this review differentiated quality scores into two tables: the first to establish the quality of the overall study, and the second to assess the quality of the empathy component of the study. Quality scores were generated for the overall study $(0-6)$ and the empathy component $(0-5)$. Summary of included studies and assessment scores are reported in Tables 1 and 2. Quality was assessed by the first author and checked by the second. Disagreements between assessor ratings were moderated by a third reviewer. 
The ratings allocated for quality of overall research was high (rated $5-6$ ) for all but two studies (see Table 1). Mercer (1986) did not adequately address significant demographic and sample size differences between the three age groups thus confounds of ethnicity, education and marital status may have biased the results. Zimerman and Doan (2003) provided limited and ill-defined details about the sample, assessment tool, and procedure.

Although overall research quality was adequate, the quality of the empathy component tended to be low (see Table 2), with six studies ranked as moderate quality (rated 3 - 4: Barr et al., 2014; Graham, 1993; Hodges, et al., 2010; Rajhans, Missana, Krol, \& Grossmann, 2015; Rodriguez, Smith, \& Silvia, 2016a, 2016b). Most lowquality scores can be attributed to the minor role empathy played in the studies. For example, two studies (Lounsbury and Bates, 1982; Sierau et al., 2016) did not introduce empathy until the methods section, implying minor variable role. Only four studies presented a multidimensional definition of empathy and appropriately matched measures (Graham, 1993; Hodges, et al., 2010; Rodriguez, et al., 2016a, 2016b), although another four studies used a multidimensional measure (Barr, et al., 2014; Fairbrother, Barr, Pauwels, Brant, \& Green, 2015; Sierau, et al., 2016; Zimerman and Doan, 2003). Quality scores were reduced as sample groups tended to be socioeconomically skewed towards advantaged participants which reduced the generalisability of findings.

\section{Results}

The 13 identified studies published between 1982 and 2017 (see Table 1) all used a quantitative approach and were predominantly cross-sectional design. Two articles analysed data from one research program conducted with 98 women randomly assigned into one of two experimental conditions (Barr, et al., 2014; Fairbrother, et al., 2015). 
However, the articles differ in research aims and constructs and this review will treat them as independent studies. Similarly, the participant sample $(n=108)$ in one study (Rodriguez, et al., 2016a) was increased to 203 women in a subsequent study (Rodriguez, et al., 2016b) to permit more sophisticated modeling and statistical analysis. The two studies are reported individually.

All studies were conducted in developed countries, with participants recruited from a range of settings including hospitals, health facilities, and childbirth and childcare clinics. Additional recruitment strategies included contacting women from birth notices, birth records, a university database of research volunteers, and community advertising. Five studies explicitly defined the final sample as women of middle class socioeconomic status, two reported samples of predominantly well-educated, Caucasian, married or cohabitating women with moderate to high household incomes, and another described their sample as 'fairly well educated'. Mercer (1986) and Rodriguez, et al. (2016a, 2016b) recruited participants from diverse socioeconomic backgrounds, although the samples were heavily weighted towards families with socioeconomic disadvantage, the group specifically targeted by Sierau, et al. (2016). Zimerman and Doan (2003) recruited mothers of Down Syndrome children through associated websites and newsletters. In summary, results of included studies were predominately derived from convenience sampling of women of social and economic advantage.

Turning to design, three studies were longitudinal, although only Sierau, et al. (2016) measured empathy more than once-at pre-birth and 24 months postpartum. Jia, Kotila, Schoppe-Sullivan, \& Kamp Dush (2016) and Mercer (1986) collected data to nine months postpartum but measured empathy only once (pre-birth and four months postpartum, respectively). 


\section{How has empathy in mothers been conceptualised and measured?}

The broad conceptualisation of empathy recognises two forms: cognitive empathy (to understand others' emotions) and affective empathy (to feel the emotions of others) (Decety and Jackson, 2004). In the majority of included studies, empathy was not the primary interest and was incorporated as a potential predictor or influencer of parental behavior (see Table 1). Consequently, few studies conceptualised empathy in a comprehensive or multidimensional way and many did not provide strong theoretical links between empathy and study outcomes.

All but one study measured empathy by self-report and $77 \%(n=10)$ of the studies used the Interpersonal Reactivity Index (IRI: Davis, 1983). The IRI has increasingly become the most popular self-report measure of empathy because: a) the independent subscales tap into four dimensions (perspective taking, empathic concern, personal distress and fantasy); b) it has been standardised; and c) it reports high validity and reliability (Konrath, 2011). Fairbrother, et al. (2015) was the only study which reported all four subscales. Barr, et al. (2014) used the same dataset but did not report means while Graham (1993) reported the summed mean total of the four subscales. The remaining seven studies reported different variations of subscales and scoring methods. Variations in IRI subscales administered, adaptations, and decisions on how scores were indexed prohibited comparison across studies. Nor are there published norms to compare IRI empathy scores to the general population.

\section{Is empathy enhanced or impaired during pregnancy or early motherhood?}

The analysis provided little evidence to determine if empathy is enhanced or impaired during pregnancy or early motherhood as only one cross-sectional study directly compared empathy capacity of pregnant women and new mothers to other women. 
Hodges et al. (2010) asked participants to rate their empathic concern for a woman describing her experience of new motherhood. Mothers reported greater empathy and understanding than non-mothers and pregnant women but were no more accurate in guessing the thoughts of the target than the others. The implication is that motherhood might initiate stronger feelings of empathy for others but does not guarantee improved perspective taking skills.

A second study (Sierau, et al., 2016) measured empathy longitudinally to evaluate the effectiveness of a home visitation program supporting socioeconomically disadvantaged women as they transitioned into parenthood. The IRI was administered at 36 weeks gestation $(n=394)$ and at 24 months postpartum $(n=178)$. Overall program effects were minimal and small in magnitude. The authors found little change in empathy scores from pregnancy to two years postpartum in women who received home visits or controls.

Mercer (1986) used a cross-sectional design to compare empathy levels across three age groups of first-time new mothers (15 to 19 years, 20 to 29 years, and 30 to 42 years). Teenage mothers were significantly less empathic than mothers in their twenties, with older mothers in between. Association between mothers' age and empathy was non-significant.

\section{What is the relationship between empathy and quality of mothering?}

\section{Positive maternal behaviours}

Several studies provided evidence of an association between mothers' empathy and maternal behaviours which enrich the mother-child relationship. Kochanska, Friesenborg, Lange, \& Martel (2004) found that mothers' empathy made a small contribution to mothers' responsiveness to their infants, assessed through observation of 
a 45-minute session of mother-infant interaction. In another observation study, Graham (1993) reported mothers' empathy accounted for $42 \%$ of variance in mothers' responsiveness. Higher empathy correlated with more positive parenting behaviour in teenage mothers, but not in older mothers (Mercer, 1986). Zimerman and Doan (2003) found that higher empathy was associated with increased attachment behavior towards the fetus such as talking to, dreaming about, and touching the baby although this finding was specific to mothers of a Down syndrome child and cannot be inferred to all mothers.

\section{Negative maternal behaviours.}

There were links between, on the one hand dysfunctional empathy (related to increased 'personal distress'), and on the other hand, maternal behaviour unfavourable to infant care and wellbeing. Personal distress is the aversive aspect of affective empathy described as "self-orientated feelings of personal anxiety and unease in tense interpersonal settings" (Davis, 1983). High personal distress appeared a risk factor for frustration and thoughts of harming the child. Barr, et al. (2014) asked 48 first-time mothers of babies less than six months old to continuously rate their frustration while listening to a baby cry for 10 minutes. Higher personal distress and lower cognitive empathy were associated with higher frustration. The authors attributed the findings to chance (two of 16 possible outcomes) but classed the direction of association as theoretically meaningful.

Equivalent data was collected from a matched control group of 50 first-time mothers who listened to 10 minutes of baby cooing (Fairbrother, et al., 2015). Across the total sample of 97 mothers, empathic concern combined with trait anger significantly predicted thoughts of infant harm. A one-point decrease in empathic concern increased the odds of having intrusive thoughts by 3.24 . However, when 
controlling for whether the mothers listened to crying or cooing, personal distress became the significant predictor of harm thoughts. A one-point increase in personal distress more than doubled the odds of having intrusive thoughts of harm towards the infant. Jia, et al. (2016) found that pregnant women who reported higher personal distress spent less time in routine childcare such as feeding and bathing at three months postpartum than women with lower distress. Interestingly, empathic personal distress did not influence the amount of time women spent engaging with their children in enriching activities or non-workday childcare.

Lower cognitive and affective empathy predicted negative attribution to children's behaviour (a known risk for parent-child abuse) and correlated moderately with abuse risk (Rodriguez, et al., 2016a). The authors subsequently doubled the sample size and refined the path analysis to incorporate associated concepts (Rodriguez, et al., 2016b). This second study reflected previous findings and found that lower empathy also predicted more intense emotional reactivity which in turn predicted negative attributions.

Reduced affective empathy corresponded to unfavourable reactions to baby cries. Lounsbury and Bates (1982) found that mothers' affective empathy was the strongest predictor of response to cries, compared to reported happiness, nurturance, irritation with infant, and acceptance of the maternal role. Small to medium sized correlations showed that more empathic women rated easy/average infant crying as less spoiled than less empathic women, and difficult infant cries as less irritating.

\section{Is there an association between mothers' empathy and child development?}

Two studies examining child development found correlations between mothers' empathy and their baby's characteristics of anger, attention, and sensitivity to others' distress. Rajhans, et al. (2015) found if infants are high on fearfulness, their response to 
emotion is modulated by mothers' self-rated empathy. If the mother rated high on empathy, the infants showed low attention allocation (indexed as neural activity recorded using EEG) when presented with computer images of bodily expressions of fear. If the mother had low empathy, infants showed high attention to the fearful stimuli. The authors theorised that a mother's empathy has a protective effect on fearful infants by reducing sensitivity to emotional stimuli to help them cope. Kochanska, et al. (2004) observed mother-child interactions to assess infants' characteristics of joy, anger, fear, and attention. They found significant correlations with small effect sizes which demonstrated that infants of more empathic mothers exhibited more focused attention and were less prone to anger.

\section{Is there an association between empathy and mothers' psychological wellbeing?}

Personal distress was associated with increased anxiety, however higher empathy was linked to better coping. Jia et al. (2016) found a weak association between mothers' empathic personal distress and negative mood, but only at three months postpartum. Empathic personal distress was also positively associated with mothers' anxiety, with

moderate effect at three months. Two studies (Rodriguez, et al., 2016a, 2016b) reported moderately strong correlations (i.e. $r$ values between .3 to .5 ) indicating lower empathy was associated with a decreased ability to restore emotional balance after distress and lower tolerance to discomfort and frustration. Mothers with higher empathy reported a higher sense of coping and greater social support satisfaction (Rodriguez, et al., 2016b).

\section{Discussion}

This review provided insight into the capacity and influence of empathy in pregnant women and new mothers. The relatively sparse studies in this field prohibited a comprehensive evaluation of fluctuations in empathy capacity. Only one study (Hodges, 
et al., 2010) directly compared empathy of new mothers, non-mothers, and pregnant women, finding enhanced affective empathy but not cognitive empathy in new mothers. However, the obvious bias of this study was the likelihood that mothers' empathy was enhanced by knowledge of a shared experience with the target. Familiarity with a subject enriches perception of shared affinity with others (Preston and de Waal, 2002).

A second comparison study (Mercer, 1986) found weak evidence that teenage mothers tended to be less empathetic than older mothers, but this is may be attributed to typical human development. A trajectory of empathy growth is observed across adolescence and explained within the context of cognitive maturation and emotion regulation during puberty (Hawk et al., 2013). It is possible that teenage mothers are at greater risk of low empathy due to immaturity and may be less responsive to their infants. However, limitations include low internal reliability of the empathy index which incorporated items relative to interpersonal hostility, avoidance, and denial. The relatively low alpha indicated a high degree of measurement error and diminished the credibility of the data as an accurate measure of empathy in this sample.

Several studies support a link between mothers' decreased empathy and reduced responsiveness to her infant, with Graham (1993) reporting one of the strongest individual findings in this review. This is consistent with prior research findings that mothers who demonstrated greater empathic understanding of their infant had higher maternal sensitivity (Coyne, Low, Miller, Seifer, \& Dickstein, 2007; Leerkes, 2010). Empathic mothers tend to prioritise their infants' needs over their own and are more likely to understand and respond to their infant sensitively (Dix, 1992).

Mothers' empathy research had a largely 'negative' (or deficit-oriented) cast: most studies explored how empathy deficits are expressed in negative parenting behaviours and attitudes rather than examining the possibility, for example, that 
motherhood had pay-offs in terms of general or specific empathy enhancement. Dysfunctional empathy in mothers was found to be a primary predictor of risk for maternal aggression through the mechanisms of negative attributions and emotional overreaction to infant behaviour (Rodriguez, et al., 2016a, 2016b). Similarly, mothers with lower empathy and higher personal distress were more likely to have thoughts of infant harm (Fairbrother, et al., 2015). These findings are consistent with broader research which links empathy deficits to aggression (Blair, 2010; Vachon and Lynam, 2016). Similarly, mothers of school-aged children at high risk for child physical abuse reported deficits in perspective taking and greater empathic personal distress than nonmaltreating mothers (de Paúl, et al., 2008).

Experimental studies have established that personal distress is the dominant empathic response to others when the observer is self-focused and egocentric and lacking an appreciation of another's experience through their eyes (Decety \& Lamm, 2009). The capacity to take another's perspective is reduced in conditions of distraction or psychosocial stress (Chambers \& Davis, 2012; Tomova, von Dawans, Heinrichs, Silani, \& Lamm, 2014). Consistent orientation to the perspective of a distressed infant may be challenging in the context of motherhood when the demands of childcare combined with fatigue limit capacity or motivation to make necessary mental adjustments. Personal distress evokes the need to escape the negative emotion (Batson, 2011) but when it is not possible to leave the situation, alleviating the other's distress, such as comforting a crying infant, is an alternate solution. Personal distress appears to be pivotal in mother's emotional and behavioural response to her infant, and more research is urgently needed to open avenues for effective screening and intervention for at-risk mothers. 
The link between mother's empathy and poor parenting may be partially explained by irritation or distress to infant crying. A large study in the Netherlands reported that nearly $6 \%$ of parents had smothered, slapped or shaken their six-month-old baby in response to crying (Reijneveld, van der Wal, Brugman, Hira Sing, \& VerlooveVanhorick, 2004). Greater empathy facilitates a mother's ability to adopt the infant's perspective and respond appropriately (Lin and McFatter, 2012). Studies in this review found that more empathic women were less frustrated or irritated by baby crying and less likely to make negative judgments about the infant (Barr, et al., 2014; Lounsbury and Bates, 1982). Empathy thus appears to act as a buffer against abusive parenting. The review findings illustrate that poor empathy in mothers is associated with insensitive or harsh parenting behaviours which have dire implications on the wellbeing of their children. The finding is a clear signal that a better understanding of empathy has implications beyond theoretical interest and is critical to improving child outcomes. Research in this important field should be a high priority to drive research funding to investigate the factors or conditions which lead to empathy fluctuations and inform maternity services practices and child welfare development.

Prior research has shown that empathy is diminished in those with depression (Thoma et al., 2011). However, only one study in this review examined the relationship. Jia, et al. (2016) found a small association between higher empathic personal distress and negative mood. This is not unique to mothers, as personal distress is associated with depressive symptoms in individuals with schizophrenia (Abramowitz, Ginger, Gollan, \& Smith, 2014), and in chronically depressed patients compared to healthy controls (Domes et al., 2016). McCullough Jr (2003) states that chronically depressed patients are unable to engage in true empathy for others because they perceive the world through an egocentric perspective. Coyne, et al. (2007) found mothers who reported higher 
depression scores were less attuned to their child's perspective, less interested in their child's experience, and were unaware of their own emotional impact on their child. As depressive symptoms increased, sensitive parenting behaviour declined. Mothers in the Jia, et al. (2016) study reported relatively low levels of depressive symptoms and, combined with a high attrition rate of over $50 \%$ of potentially depressed women, may be an under-estimation of the true level of the relationship between depression and empathic response in mothers.

Evidence of child outcomes associated with mothers' empathy levels was limited. Rajhans, et al. (2015) found that infants of mothers with high affective empathy were more attentive to expressions of fear/distress compared to expressions of happiness, suggesting a positive correlation between mothers and infants empathic tendencies. With regard to infants' temperament, Kochanska, et al. (2004) found infants of more empathic mothers exhibited more focused attention and were less prone to anger than infants of lower-empathy mothers. The limited review findings suggest mothers' empathy may influence the temperament or nature of their children from a very early age.

The sole intervention study (Sierau, et al., 2016) included in this review did not show any change in empathy at the conclusion of the trial. However, empathy was not the focus of training per se, but was hypothesised to improve as a consequence of support to enhance the mother-child relationship. Empathy interventions are commonly taught to physicians, therapists, and nurses but not maternity health professionals. The single reported intervention for mothers (Oppenheim, Goldsmith, \& Koren-Karie, 2004) was a therapeutic preschool program for children with behavioural and emotional problems and their mothers. The program did not provide structured empathy training but after seven months of therapeutic intervention the number of mothers classified as 
'insightful' increased from 3 to 16 of the 32 mothers with an associated improvement in their children's behavior (Oppenheim, et al., 2004). Maternity health professionals with an understanding of the capacity, impediments, and consequences of empathy in pregnant women and new mothers can sensitively coach new mothers to be responsive to their babies.

\section{Limitations}

The findings of this review should be interpreted in light of certain limitations. Empathy has not been well researched in this population, with only 13 studies identified. Few studies placed empathy as a central theme within the research design, as demonstrated by a paucity of definitional parameters and theoretical linkages, and reliance on brief self-report indices of empathy. The evidence was not sufficient to make causal inferences, particularly in the absence of a body of longitudinal research with repeated measures. It is possible that results of empathy measures in new mothers are sensitive to the staging of the testing. If a mother is tested at a period of peak exhaustion for example, possible improvements in empathy may be masked. Empathy is a complex and multidimensional concept involving both cognitive perspective-taking and emotional responses, and the singular approach adopted by most studies diminished the strength of findings.

The search parameters excluded studies of maternal empathy (i.e., studies which measured empathy in the context of mother-child relationship) which may have led to the exclusion of valuable research. Much of the research of empathy in new mothers is generated by the child attachment field which examines maternal qualities predicted to facilitate strong and secure mother-child bonding. Maternal empathy, typically indexed according to behaviours observed during mother-child interactions, is subject to the influence of interpersonal factors such as the temperament of the child, the mother's 
beliefs and attitudes concerning childrearing, and the mother's state of mind (Emery, McElwain, Groh, Haydon, \& Roisman, 2014). However, empathy-related responding in real life will differ to subjective measures of empathy, and a multimethod approach could tap into the dimensions of empathy within the context of the mother-child relationship.

Generalisability of review findings was limited because sample characteristics, at times insufficiently reported, tended to be skewed toward women from higher socioeconomic status, with the exception of a handful of studies that specifically recruited disadvantaged women. The search protocol confined results to articles published in English language which could exclude important studies and limit the generalisability of results.

\section{Future research}

The present findings demonstrate the need for theory-based and well-designed studies that incorporate an experimental approach with greater sampling diversity. Future studies should place emphasis on validated and reliable measures that encompass the multidimensional nature of empathy. More research is required to determine if empathy is enhanced or inhibited during this important life transition to motherhood. The use of generalised measures of empathy may be missing one of the benefits of motherhood to a woman's empathy development: focused improvements related to a mother's greater capacity to read an infant's responses and cognitive states. With only a single study employing repeated measures in a longitudinal design, current studies cannot answer this critical question. New motherhood is different to the other major life stressors identified by Holmes and Rahe (1967) in that the 'crisis' is more chronic, with the stress associated with parenting spread over a longer period. Choosing appropriate time points to detect change thus becomes more critical. Finally, research into empathy in fathers 
may shed light onto parental empathy in general in the absence of some of the hormonal complexity that motherhood adds to the picture.

\section{Conclusion}

This review found little empirical evidence mapping empathy capacity in pregnancy or postpartum, its characteristics or impediments. The findings support the view that impaired empathy in mothers, due most notably to high personal distress, is associated with risk of neglect or maltreatment of children and partially explained by mothers' aversive response to infant cries. The lack of control studies limit conclusions about associations between mothers' capacity for empathy and the quality of her parenting.

Not only is empathy considered critical to forming a nurturing bond between a mother and her infant, it is thought to influence the quality of mother's interpersonal relationships as she seeks to develop social networks that support her new role and to sustain close relationships with significant others who contribute to baby care (Manuel, Martinson, Bledsoe-Mansori, \& Bellamy, 2012). Motherhood represents a special case for empathy researchers, as motherhood can be predicted in advance, and offers an event that both challenges (for example through sleep deprivation) and motivates (through the arrival of a significant 'other' who requires the development of empathy in the absence of verbal communication) the development of empathy. This review indicates both the value of extending and expanding research in this field and underlines the paucity of work examining what appears to be a key predictor of positive child development outcomes.

\section{Disclosure of interest}

The authors report no conflict of interest. 


\section{References}

Aber, C., Weiss, M., \& Fawcett, J. (2013). Contemporary women's adaptation to motherhood: The first 3 to 6 weeks postpartum. Nursing Science Quarterly, 26(4), 344-351. doi:10.1177/0894318413500345

Abramowitz, A. C., Ginger, E. J., Gollan, J. K., \& Smith, M. J. (2014). Empathy, depressive symptoms, and social functioning among individuals with schizophrenia. Psychiatry Research, 216(3), pp. 325-332. doi:10.1016/j.psychres.2014.02.028

Ainsworth, M. S. (1979). Infant-mother attachment. American psychologist, 34(10), pp. 932-937. doi:10.1037//0003-066X.34.10.932

Barr, R. G., Fairbrother, N., Pauwels, J., Green, J., Chen, M., \& Brant, R. (2014). Maternal frustration, emotional and behavioural responses to prolonged infant crying. Infant Behavior \& Development, 37(4), pp. 652-664. doi:10.1016/j.infbeh.2014.08.012

Batson, C. D. (2011). Altruism in humans New York: Oxford University Press.

Batson, C. D., Sympson, S. C., Hindman, J. L., Decruz, P., Todd, R. M., Weeks, J. L., . . . Burns, C. T. (1996). "I've been there, too": Effect on empathy of prior experience with a need. Personality and Social Psychology Bulletin, 22(5), pp. 474-482. doi:10.1177/0146167296225005

Blair, R. J. R. (2010). Empathy, moral development, and aggression: A cognitive neuroscience perspective. In W. F. Arsenio \& E. A. Lemerise (Eds.), Emotions, aggression, and morality in children : Bridging development and psychopathology (pp. 97-114). Washington, D.C: American Psychological Association.

Chambers, J. R., \& Davis, M. H. (2012). The role of the self in perspective-taking and empathy: Ease of self-simulation as a heuristic for inferring empathic feelings. Social Cognition, 30(2), 153-180. doi:10.1521/soco.2012.30.2.153

Coyne, L. W., Low, C. M., Miller, A. L., Seifer, R., \& Dickstein, S. (2007). Mothers' empathic understanding of their toddlers: Associations with maternal depression and sensitivity. Journal of Child and Family Studies, 16(4), pp. 483-497. doi:10.1007s 10826-006-9099-9

Davies, S. J., Lum, J. A. G., Skouteris, H., Byrne, L. K., \& Hayden, M. J. (2018). Cognitive impairment during pregnancy: A meta-analysis. Medical Journal of Australia, 208(1), pp. 35-40. doi:10.5694/mja17.00131

Davis, M. H. (1983). Measuring individual differences in empathy: Evidence for a multidimensional approach. Journal of Personality and Social Psychology, 44(1), pp. 113-126. doi:10.1037//0022-3514.44.1.113

de Paúl, J., Pérez-Albéniz, A., Guibert, M., Asla, N., \& Ormaechea, A. (2008). Dispositional empathy in neglectful mothers and mothers at high risk for child physical abuse. Journal of Interpersonal Violence, 23(5), pp. 670-684. doi: $10.1177 / 0886260507313532$

de Waal, F. B. M. (2009). The age of empathy: Nature's lessons for a kinder society New York: Crown Publishing.

Decety, J., \& Jackson, P. L. (2004). The functional architecture of human empathy. Behavioral and Cognitive Neuroscience Reviews, 3(2), pp. 71-100. doi:10.1177/1534582304267187

Decety, J., \& Lamm, C. (2009). Empathy versus personal distress: Recent evidence from social neuroscience. In J. Decety \& W. Ickes (Eds.), The social neuroscience of empathy. Cambridge: MIT Press. 
Deeks, J. J., Higgins, J., \& Altman, D.G. (2008). Analysing data and undertaking metaanalyses. Cochrane handbook for systematic review of interventions: Cochrane book series, pp. 243-296.

DeKlyen, M., \& Greenberg, M. T. (2008). Attachment and psychopathology in childhood. In J. Cassidy \& P. Shaver (Eds.), Handbook of attachment: Theory, research, and clinical applications (pp. 637-665). New York: Guilford Press.

Dix, T. (1992). Parenting on behalf of the child: Empathic goals in the regulation of responsive parenting. In I. E. Sigel, A. V. McGillicuddy-DeLisi \& J. J. Goodnow (Eds.), Parental belief systems: The psychological consequences for children (2nd ed., pp. 319-346). Hillsdale, England: Lawrence Erlbaum Associates, Inc.

Domes, G., Spenthof, I., Radtke, M., Isaksson, A., Normann, C., \& Heinrichs, M. (2016). Autistic traits and empathy in chronic vs. episodic depression. Journal of Affective Disorders, 195, pp. 144-147. doi:10.1016/j.jad.2016.02.006

Emery, H. T., McElwain, N. L., Groh, A. M., Haydon, K. C., \& Roisman, G. I. (2014). Maternal dispositional empathy and electrodermal reactivity: Interactive contributions to maternal sensitivity with toddler-aged children. Journal of Family Psychology, 28(4), pp. 505-515. doi:10.1037/a0036986

Fairbrother, N., Barr, R. G., Pauwels, J., Brant, R., \& Green, J. (2015). Maternal thoughts of harm in response to infant crying: An experimental analysis. Archives of Women's Mental Health, 18(3), pp. 447-455. doi:10.1007/s00737014-0471-2

Farrant, B. M., Devine, T. A. J., Maybery, M. T., \& Fletcher, J. (2012). Empathy, perspective taking and prosocial behaviour: The importance of parenting practices. Infant and Child Development, 21(2), pp. 175-188. doi:10.1002/icd.740

Gohier, B., Ferracci, L., Surguladze, S. A., Lawrence, E., El Hage, W., Kefi, M. Z., . . . Le Gall, D. (2009). Cognitive inhibition and working memory in unipolar depression. Journal of Affective Disorders, 116(1-2), pp. 100-105. doi:10.1016/j.jad.2008.10.028

Graham, M. V. (1993). Parental sensitivity to infant cues: Similarities and differences between mothers and fathers. Journal of Pediatric Nursing, 8(6), pp. 376-384. Retrieved from https://www-ncbi-nlm-nihgov.libraryproxy.griffith.edu.au/pubmed/8133436

Hawk, S. T., Keijsers, L., Branje, S. T. J., van der Graaff, J., de Wied, M., \& Meeus, W. H. J. (2013). Examining the Interpersonal Reactivity Index (IRI) among early and late adolescents and their mothers. Journal of Personality Assessment, 95(1), pp. 96-106. doi:10.1080/00223891.2012.696080

Heinrichs, M., von Dawans, B., \& Domes, G. (2009). Oxytocin, vasopressin, and human social behavior. Frontiers in Neuroendocrinology, 30(4), pp. 548-557. doi:10.1016/j.yfrne.2009.05.005

Hodges, S. D., Kiel, K. J., Kramer, A. D., Veach, D., \& Villanueva, B. R. (2010). Giving birth to empathy: The effects of similar experience on empathic accuracy, empathic concern, and perceived empathy. Personality and Social Psychology Bulletin, 36(3), pp. 398-409. doi:10.1177/0146167209350326

Hoekzema, E., Barba-Müller, E., Pozzobon, C., Picado, M., Lucco, F., García-García, D., . . . Vilarroya, O. (2017). Pregnancy leads to long-lasting changes in human brain structure. Nature Neuroscience, 20, pp. 287-296. doi:10.1038/nn.4458

Holmes, T. H., \& Rahe, R. H. (1967). The social readjustment rating scale. Journal of Psychosomatic Research, 11(2), 213-218. doi:10.1016/0022-3999(67)90010-4 
Huang, Z. J., Lewin, A., Mitchell, S. J., \& Zhang, J. (2012). Variations in the relationship between maternal depression, maternal sensitivity, and child attachment by race/ethnicity and nativity: findings from a nationally representative cohort study. Maternal and Child Health Journal, 16(1), 40-50. doi:10.1007/s10995-010-0716-2

Jia, R., Kotila, L. E., Schoppe-Sullivan, S. J., \& Kamp Dush, C. M. (2016). New parents' psychological adjustment and trajectories of early parental involvement. Journal of Marriage and Family, 78(1), pp. 197-211. doi:10.1111/jomf.12263

Kochanska, G., Friesenborg, A. E., Lange, L. A., \& Martel, M. M. (2004). Parents' personality and infants' temperament as contributors to their emerging relationship. Journal of Personality and Social Psychology, 86(5), pp. 744-759. doi:10.1037/0022-3514.86.5.744

Konrath, S. H. (2011). Changes in dispositional empathy in American college students over time: A meta-analysis. Personality and Social Psychology Review, 15(2), pp. 180-198. doi:10.1177/1088868310377395

Leerkes, E. M. (2010). Predictors of maternal sensitivity to infant distress. Parenting Science and Practice, 10(3), pp. 219-239. doi:10.1080/15295190903290840

Liberati, A., Altman, D. G., Tetzlaff, J., C, M., Gotzsche, P., Ioannidis, J. P., . . . Moher, D. (2009). The PRISMA statement for reporting systematic reviews and metaanalyses of studies that evaluate healthcare interventions: Explanation and elaboration. PLoS Medicine, 6(7). doi.e1000100.10.1371/journal.pmed.1000100

Lin, H., \& McFatter, R. (2012). Empathy and distress: Two distinct but related emotions in response to infant crying. Infant Behavior and Development, 35(4), pp. 887897. doi:10.1016/j.infbeh.2012.08.001

Lounsbury, M. L., \& Bates, J. E. (1982). The cries of infants of differing levels of perceived temperamental difficultness: Acoustic properties and effects on listeners. Child Development, 53(3), pp. 677-686. doi:10.1111/j.14678624.1982.tb03441.x

Manuel, J. I., Martinson, M. L., Bledsoe-Mansori, S. E., \& Bellamy, J. L. (2012). The influence of stress and social support on depressive symptoms in mothers with young children. Social Science and Medicine, 75(11), pp. 2013-2020. doi:10.1016/j.socscimed.2012.07.034

Martins, C., \& Gaffan, E. A. (2000). Effects of early maternal depression on patterns of infant-mother attachment: A meta-analytic investigation. The Journal of Child Psychology and Psychiatry and Allied Disciplines, 41(6), 737-746. doi:10.1017/S0021963099005958

McCullough Jr, J. P. (2003). Treatment for chronic depression using Cognitive Behavioral Analysis System of Psychotherapy (CBASP). [Review]. Journal of Clinical Psychology, 59(8), pp. 833-846. doi:10.1002/jclp.10176

Mehrabian, A., \& Epstein, N. (1972). A measure of emotional empathy. Journal of personality, 40(4), pp. 525-543. doi:10.1111/j.1467-6494.1972.tb00078.x

Mercer, R. T. (1986). The relationship of developmental variables to maternal behavior. Research in Nursing \& Health, 9(1), pp. 25-33. doi:10.1002/nur.4770090106

Oppenheim, D., Goldsmith, D., \& Koren-Karie, N. (2004). Maternal insightfulness and preschoolers' emotion and behavior problems: Reciprocal influences in a therapeutic preschool program. Infant Mental Health Journal, 25(4), pp. 352367. doi:10.1002/imhj.20010

Pickering, C., \& Byrne, J. (2014). The benefits of publishing systematic quantitative literature reviews for $\mathrm{PhD}$ candidates and other early-career researchers. Higher Education Research \& Development, 33(3), pp. 534-548. 
doi:10.1080/07294360.2013.841651

Preston, S. D., \& de Waal, F. B. M. (2002). Empathy: Its ultimate and proximate bases. Behavioral and Brain Sciences, 25(1), pp. 1-72. doi:10.1017/S0140525X02000018

Rajhans, P., Missana, M., Krol, K. M., \& Grossmann, T. (2015). The association of temperament and maternal empathy with individual differences in infants' neural responses to emotional body expressions. Development and Psychopathology, 27(4), pp. 1205-1216. doi:10.1017/S0954579415000772

Ranson, K. E. (2008). The effect of parent-child attachment relationships on child biopsychosocial outcomes: A review. Early Child Development and Care, 178(2), pp. 129-152. doi:10.1080/03004430600685282

Reck, C., Hunt, A., Fuchs, T., Weiss, R., Noon, A., Moehler, E., . . Mundt, C. (2004). Interactive regulation of affect in postpartum depressed mothers and their infants: an overview. Psychopathology, 37(6), 272-280. doi:10.1159/000081983

Reijneveld, S. A., van der Wal, M. F., Brugman, E., Hira Sing, R. A., \& VerlooveVanhorick, S. P. (2004). Infant crying and abuse. The Lancet, 364(9442), pp. 1340-1342. doi:https://doi.org/10.1016/S0140-6736(04)17191-2

Reynolds, A. C., \& Banks, S. (2010). Total sleep deprivation, chronic sleep restriction and sleep disruption. Progress in Brain Research, 185, pp. 91-103. doi:10.1016/B978-0-444-53702-7.00006-3

Rocchetti, M., Radua, J., Paloyelis, Y., Xenaki, L.-A., Frascarelli, M., Caverzasi, E., . . . Fusar-Poli, P. (2014). Neurofunctional maps of the 'maternal brain' and the effects of oxytocin: A multimodal voxel-based meta-analysis. Psychiatry and Clinical Neurosciences, 68(10), pp. 733-751. doi:10.1111/pcn.12185

Rodriguez, C. M., Smith, T. L., \& Silvia, P. J. (2016a). Multimethod prediction of physical parent-child aggression risk in expectant mothers and fathers with Social Information Processing theory. Child Abuse and Neglect, 51, pp. 106119. doi:10.1016/j.chiabu.2015.10.028

Rodriguez, C. M., Smith, T. L., \& Silvia, P. J. (2016b). Parent-child aggression risk in expectant mothers and fathers: A multimethod theoretical approach. Journal of Child and Family Studies, 25(11), pp. 3220-3235. doi:10.1007/s10826-0160481-y

Schwenck, C., Göhle, B., Hauf, J., Warnke, A., Freitag, C. M., \& Schneider, W. (2014). Cognitive and emotional empathy in typically developing children: The influence of age, gender, and intelligence. European Journal of Developmental Psychology, 11(1), pp. 63-76. doi:10.1080/17405629.2013.808994

Shamay-Tsoory, S. G. (2011). Empathic processing: Its cognitive and affective dimensions and neuroanatomical basis. In J. Decety \& W. Ickes (Eds.), The social neuroscience of empathy (pp. 215-232). Cambridge, Mass: MIT Press.

Shamay-Tsoory, S. G., \& Abu-Akel, A. (2016). The social salience hypothesis of oxytocin. Biological Psychiatry, 79(3), pp. 194-202. doi:10.1016/j.biopsych.2015.07.020

Shansky, R. M., \& Lipps, J. (2013). Stress-induced cognitive dysfunction: Hormoneneurotransmitter interactions in the prefrontal cortex. Frontiers in Human Neuroscience, 7, pp. 123-129. doi:10.3389/fnhum.2013.00123

Sherman, S., \& Stotland, E. (1978). Adding a new tool: Development of scales to measure empathy. In E. Stotland, K. E. Mathews Jr, S. E. Sherman, R. O. Hannson \& B. Z. Richardson (Eds.), Empathy, fantasy, and helping (pp. 27-44). Belverly Hills, CA: Sage.

Sierau, S., Dahne, V., Brand, T., Kurtz, V., von Klitzing, K., \& Jungmann, T. (2016). 
Effects of home visitation on maternal competencies, family environment, and child development: A randomized controlled trial. Prevention Science, 17(1), pp. 40-51. doi:10.1007/s11121-015-0573-8

Sonnby-Borgström, M., Jönsson, P., \& Svensson, O. (2003). Emotional empathy as related to mimicry reactions at different levels of information processing. Journal of Nonverbal Behavior, 27(1), 3-23. doi:10.1023/A:1023608506243

Stern, J. A., Borelli, J. L., \& Smiley, P. A. (2015). Assessing parental empathy: A role for empathy in child attachment. Attachment and Human Development, 17(1), pp. 1-22. doi:10.1080/14616734.2014.969749

Swain, J. E., Kim, P., Spicer, J., Ho, S. S., Dayton, C. J., Elmadih, A., \& Abel, K. M. (2014). Approaching the biology of human parental attachment: Brain imaging, oxytocin and coordinated assessments of mothers and fathers. Brain Research, 1580, pp. 78-101. doi:10.1016/j.brainres.2014.03.007

Tharner, A., Luijk, M. P. C. M., van Ijzendoorn, M. H., Bakermans-Kranenburg, M. J., Jaddoe, V. W. V., Hofman, A., . . Tiemeier, H. (2012). Infant attachment, parenting stress, and child emotional and behavioral problems at age 3 years. Parenting, 12(4), 261-281. doi:10.1080/15295192.2012.709150

Thoma, P., Zalewski, I., von Reventlow, H. G., Norra, C., Juckel, G., \& Daum, I. (2011). Cognitive and affective empathy in depression linked to executive control. Psychiatry Research, 189(3), pp. 373-378. doi:10.1016/j.psychres.2011.07.030

Tomova, L., von Dawans, B., Heinrichs, M., Silani, G., \& Lamm, C. (2014). Is stress affecting our ability to tune into others? Evidence for gender differences in the effects of stress on self-other distinction. Psychoneuroendocrinology, 43, 95104. doi:10.1016/j.psyneuen.2014.02.006

Vachon, D. D., \& Lynam, D. R. (2016). Fixing the problem with empathy: Development and validation of the affective and cognitive measure of empathy. Assessment, 23(2), pp. 135-149. doi:10.1177/1073191114567941

Zeifman, D. M. (2003). Predicting adult responses to infant distress: Adult characteristics associated with perceptions, emotional reactions, and timing of intervention. Infant Mental Health Journal, 24(6), pp. 597-612. doi:10.1002/imhj.10077

Zimerman, A., \& Doan, H. M. (2003). Prenatal attachment and other feelings and thoughts during pregnancy in three groups of pregnant women. Journal of Prenatal \& Perinatal Psychology \& Health, 18(2), p 131. Retrieved from http://search.proquest.com.libraryproxy.griffith.edu.au/docview/198785522?acc ountid=14543 
Table 1. Summary and quality assessment of studies

\begin{tabular}{|c|c|c|c|c|}
\hline $\begin{array}{c}\text { First author } \\
\text { Year, } \\
\text { Country }\end{array}$ & Stated aim & Design & $\begin{array}{l}\text { Sample type, } \\
\text { Sample size, } \\
\text { Age (min-max) }\end{array}$ & $\begin{array}{c}\text { Quality rating } \\
0-6\end{array}$ \\
\hline $\begin{array}{l}\text { Lounsbury } \\
1982 \\
\text { Finland }\end{array}$ & $\begin{array}{l}\text { Explore how quality of infants' cry } \\
\text { and/or characteristics of unrelated } \\
\text { listener impacts on perception of } \\
\text { 'difficult' temperament of infants }\end{array}$ & $\begin{array}{l}\text { Cross-sectional, } \\
\text { Single sample }\end{array}$ & $\begin{array}{l}\text { Middleclass first-time mothers } \\
\text { recruited from birth notices } \\
N=45 \\
M_{\text {age }}=24.7 \mathrm{yrs}\end{array}$ & $\begin{array}{l}6 \text { - Theory-based design, } \\
\text { appropriate and clear } \\
\text { methodology and analysis, } \\
\text { conclusions consistent with } \\
\text { results. }\end{array}$ \\
\hline $\begin{array}{l}\text { Mercer } \\
1986 \\
\text { US }\end{array}$ & $\begin{array}{l}\text { Investigate differences in maternal } \\
\text { behaviour between younger and older } \\
\text { mothers related to traits \& self- } \\
\text { concept }\end{array}$ & $\begin{array}{l}\text { Longitudinal, } \\
\text { Single sample }\end{array}$ & $\begin{array}{l}\text { First-time mothers recruited from } \\
\text { hospitals } \\
N=294 \\
(15-42 \text { yrs) }\end{array}$ & $\begin{array}{l}3 \text { - Theory-based design, } \\
\text { possible confounds e.g. } \\
\text { education, not accounted for, } \\
\text { unequal age group sample } \\
\text { sizes and attrition not } \\
\text { addressed. }\end{array}$ \\
\hline
\end{tabular}




\begin{tabular}{|c|c|c|c|c|}
\hline First author & & & Sample type, & Ouality rating \\
\hline $\begin{array}{l}\text { Year, } \\
\text { Country }\end{array}$ & Stated aim & Design & $\begin{array}{l}\text { Sample size, } \\
\text { Age (min-max) }\end{array}$ & $0-6$ \\
\hline
\end{tabular}

\begin{tabular}{|c|c|c|c|c|}
\hline $\begin{array}{l}\text { Graham } \\
1993 \\
\text { US }\end{array}$ & $\begin{array}{l}\text { Explore interaction between } \\
\text { characteristics of parents and infants, } \\
\text { and how characteristics relates to } \\
\text { parental sensitivity to infant cues }\end{array}$ & $\begin{array}{l}\text { Cross-sectional, } \\
\text { Single sample }\end{array}$ & $\begin{array}{l}\text { First-time mothers recruited from } \\
\text { childcare classes and birth records. } \\
N=32 \text { couples } \\
M_{\text {age }} \text { of mothers }=29 \mathrm{yrs} \\
(25-38 \mathrm{yrs})\end{array}$ & $\begin{array}{l}6 \text { - Theory-based design, } \\
\text { appropriate and clear } \\
\text { methodology and analysis, } \\
\text { conclusions consistent with } \\
\text { results. }\end{array}$ \\
\hline & & & $\begin{array}{l}N=\text { unclear, } 11 \text { mothers provided } \\
\text { quantitative data } \\
M_{\text {age }}=36.4 \mathrm{yrs}\end{array}$ & \\
\hline
\end{tabular}




$\begin{array}{cccc}\begin{array}{l}\text { First author } \\ \text { Year, }\end{array} \text { Stated aim } & \text { Design } & \text { Sample type, } & \text { Quality rating } \\ \text { Country } & & \text { Sample size, } & 0-6\end{array}$

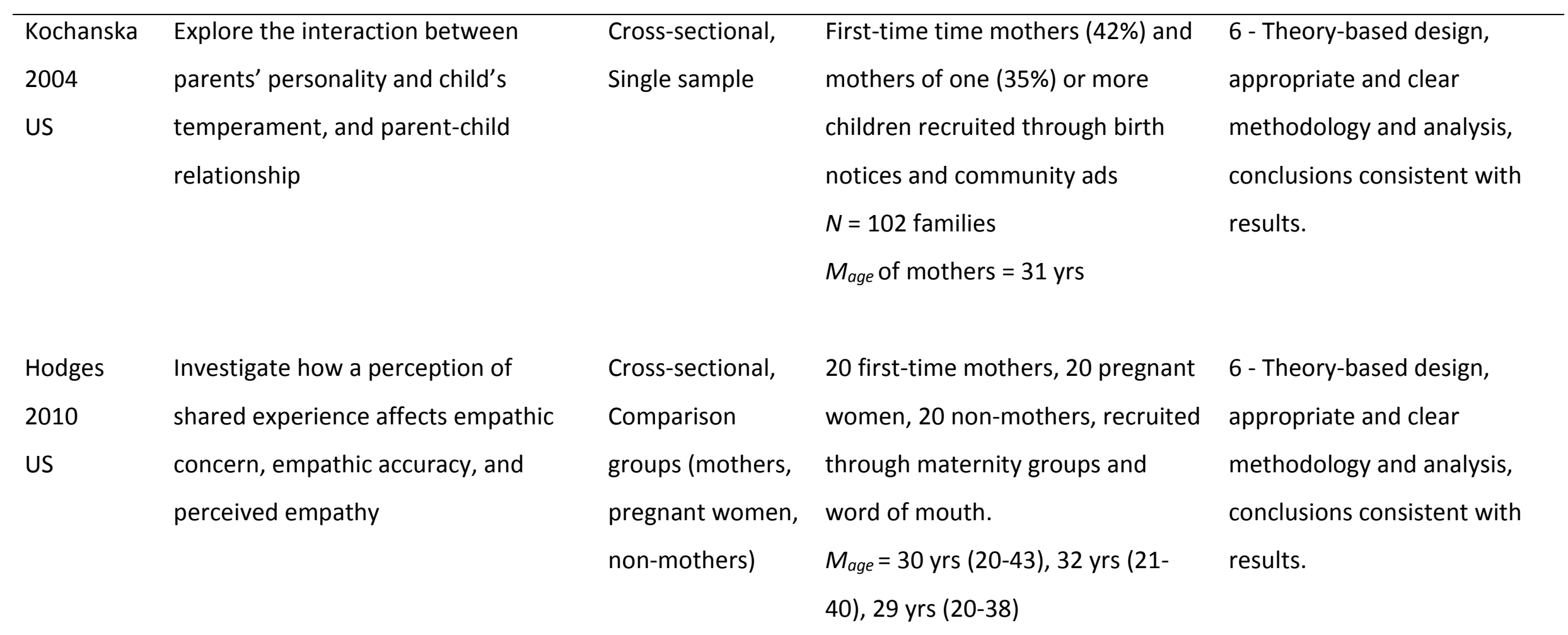




\begin{tabular}{|c|c|c|c|c|}
\hline $\begin{array}{l}\text { First author } \\
\text { Year, } \\
\text { Country }\end{array}$ & Stated aim & Design & $\begin{array}{l}\text { Sample type, } \\
\text { Sample size, } \\
\text { Age (min-max) }\end{array}$ & $\begin{array}{c}\text { Quality rating } \\
0-6\end{array}$ \\
\hline $\begin{array}{l}\text { Barr } \\
2014 \\
\text { Canada }\end{array}$ & $\begin{array}{l}\text { Investigate course of frustration } \\
\text { across time when listening to } \\
\text { prolonged infant crying, and } \\
\text { association with negative mood, } \\
\text { anger, and empathy }\end{array}$ & $\begin{array}{l}\text { Cross-sectional, } \\
\text { Comparison } \\
\text { group ( } n=50, \text { no } \\
\text { empathy data } \\
\text { included) }\end{array}$ & $\begin{array}{l}\text { Middleclass first-time mothers } \\
\text { recruited from hospitals and } \\
\text { community health centres. } \\
N=98 \\
M_{\text {age }}=31 \text { yrs }\end{array}$ & $\begin{array}{l}6 \text { - Theory-based design, } \\
\text { appropriate and clear } \\
\text { methodology and analysis, } \\
\text { conclusions consistent with } \\
\text { results. }\end{array}$ \\
\hline $\begin{array}{l}\text { Fairbrother } \\
2015 \\
\text { Canada }\end{array}$ & $\begin{array}{l}\text { Investigate intrusive thoughts of } \\
\text { infant harm in response to prolonged } \\
\text { crying, and contribution of negative } \\
\text { mood, anger, and empathy }\end{array}$ & $\begin{array}{l}\text { Cross-sectional, } \\
\text { Comparison } \\
\text { group }(n=50)\end{array}$ & Same as Barr (2014) & $\begin{array}{l}5 \text { - Theory-based design, } \\
\text { appropriate and clear } \\
\text { methodology and analysis, } \\
\text { group differences, } \\
\text { conclusions consistent with } \\
\text { results. }\end{array}$ \\
\hline
\end{tabular}




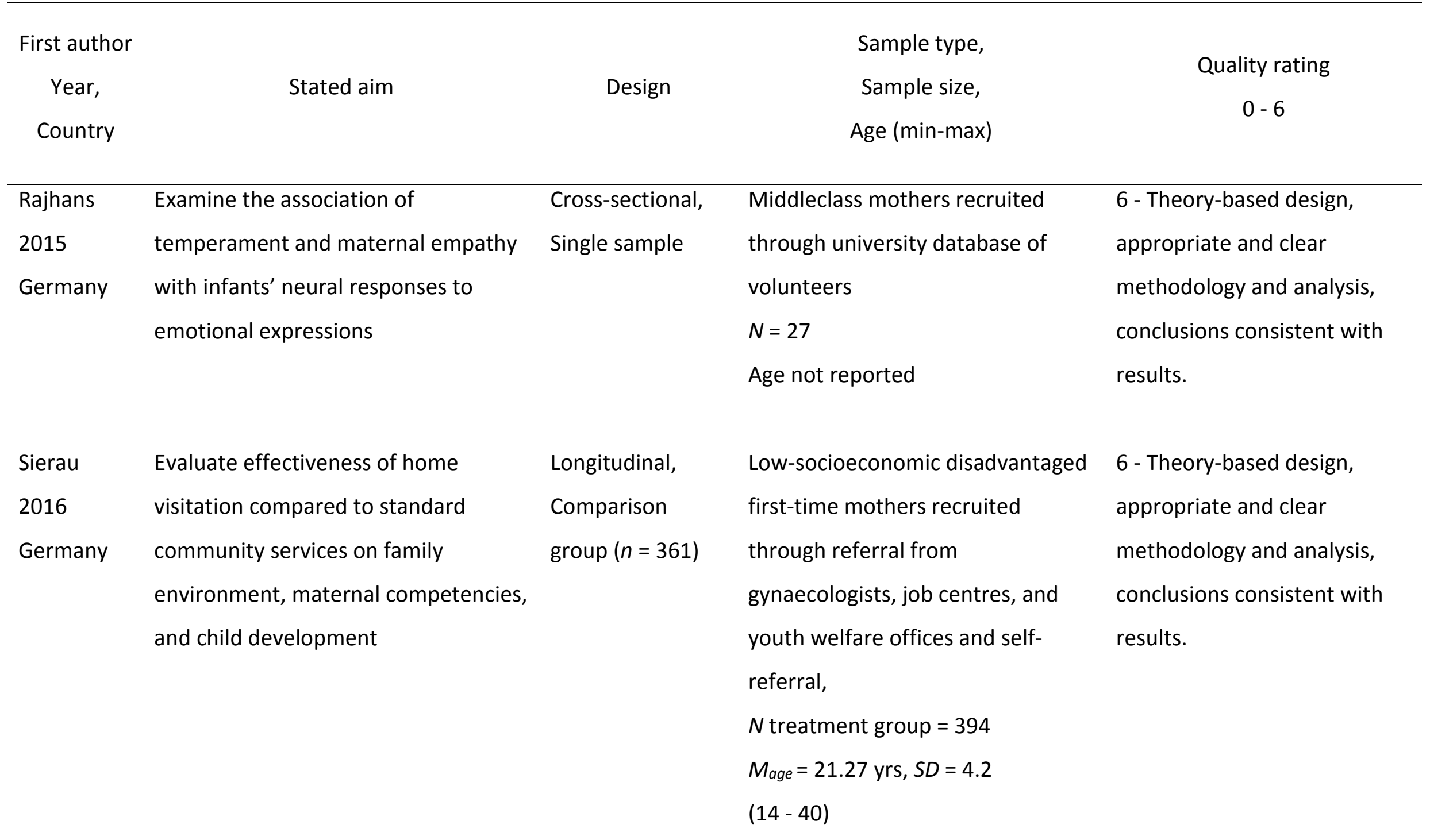




\begin{tabular}{|c|c|c|c|c|}
\hline First author & & & Sample type, & Quality rating \\
\hline $\begin{array}{l}\text { Year, } \\
\text { Country }\end{array}$ & Stated aim & Design & $\begin{array}{l}\text { Sample size, } \\
\text { Age (min-max) }\end{array}$ & $0-6$ \\
\hline
\end{tabular}

\begin{tabular}{ll}
\hline Rodriguez & Investigate parent to child aggression, \\
2016 & examining attitudes to disciple, \\
US & emotional reactivity, negative child \\
& attributes, personal history of abuse, \\
& and empathy \\
& \\
Rodriguez & Investigate parent to child aggression, \\
2016 & parent's personal vulnerabilities, \\
US & attitude to disciple, and personal \\
& resources. Sought to predict risk of \\
& PCA in first-time parents.
\end{tabular}

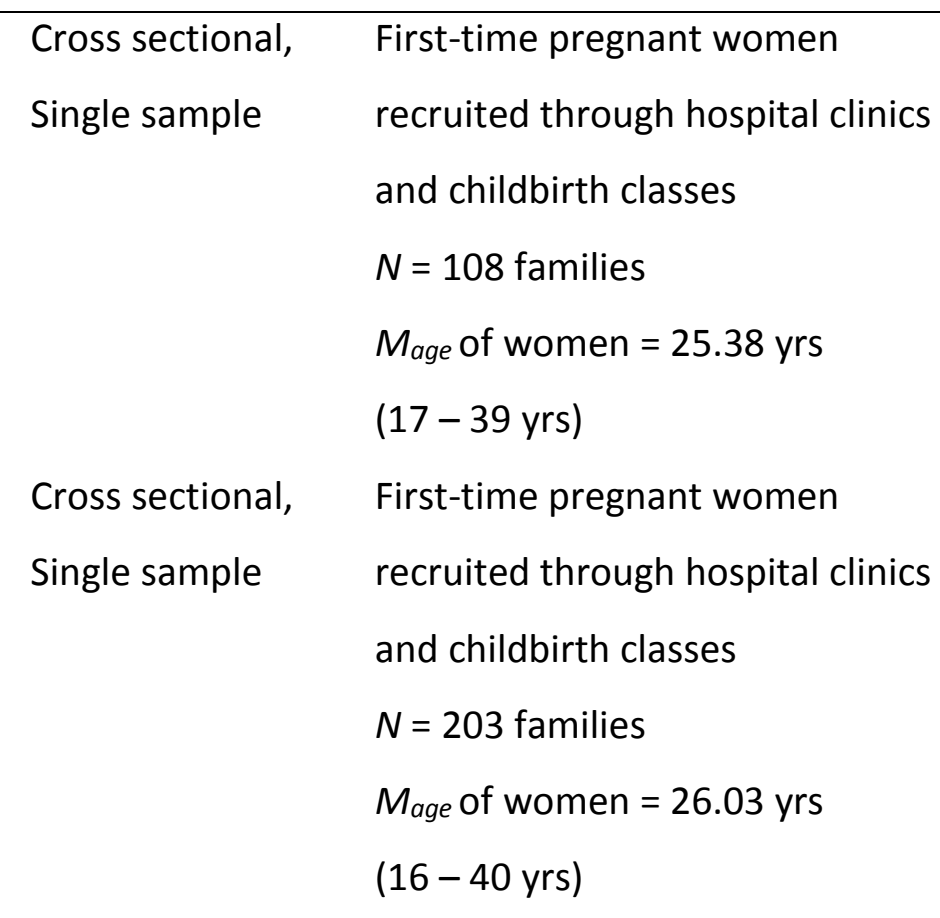

6 - Theory-based design,

appropriate and clear methodology and analysis, conclusions consistent with results.

\section{6 - Theory-based design,} appropriate and clear methodology and analysis, conclusions consistent with results. 


\begin{tabular}{|c|c|c|c|c|}
\hline $\begin{array}{l}\text { Jia } \\
2016 \\
\text { US }\end{array}$ & $\begin{array}{l}\text { Characterise and predict early } \\
\text { parental involvement time for } \\
\text { mothers and fathers, and the } \\
\text { association to aspects of parents' } \\
\text { psychological adjustment }\end{array}$ & $\begin{array}{l}\text { Longitudinal, } \\
\text { Single sample }\end{array}$ & $\begin{array}{l}\text { First-time pregnant middleclass } \\
\text { women, no recruitment details } \\
N=177 \\
M_{\text {age }}=28.33 \text { yrs, } S D=3.94\end{array}$ & $\begin{array}{l}6 \text { - Theory-based design, } \\
\text { appropriate and clear } \\
\text { methodology and analysis, } \\
\text { conclusions consistent with } \\
\text { results. }\end{array}$ \\
\hline
\end{tabular}


Table 2. Type and assessment of empathy component of studies

\begin{tabular}{|c|c|c|c|c|}
\hline $\begin{array}{c}\text { First author, } \\
\text { Empathy }\end{array}$ & $\begin{array}{c}\text { Time of } \\
\text { empathy } \\
\text { assessment }\end{array}$ & $\begin{array}{l}\text { Measure, } \\
\text { Method, } \\
\text { Reliability/ } \\
\text { Validity }\end{array}$ & Empathy findings & $\begin{array}{c}\text { Quality rating } \\
0-5\end{array}$ \\
\hline $\begin{array}{l}\text { Lounsbury (1982) } \\
\text { Affective empathy }\end{array}$ & $\begin{array}{l}4-6 \text { mths } \\
\text { postpartum }\end{array}$ & $\begin{array}{l}\text { MEE 38-item }{ }^{1} \text {, } \\
\text { self-report }\end{array}$ & $\begin{array}{l}\text { Empathy strongest predictor of responses to cries. More } \\
\text { empathic women rated easy/average infant cries as less } \\
\text { spoiled than less empathic women }(r=-.25 \& .32, p<.05) \text {, and } \\
\text { difficult infant cries as less irritating }(r=.25, p<.05) \text {. }\end{array}$ & $\begin{array}{l}2 \text { - Empathy not } \\
\text { defined, } \\
\text { unidimensional, } \\
\text { validated } \\
\text { measure. }\end{array}$ \\
\hline Mercer (1986) & 4 mths & Sherman \& & Teenagers $(n=52, M=36.29, S D=8.30)$ less empathic than 20 - & 0 - Empathy not \\
\hline $\begin{array}{l}\text { Affective \& } \\
\text { cognitive empathy, } \\
\text { avoidance, } \\
\text { hostility, \& fantasy }\end{array}$ & postpartum & $\begin{array}{l}\text { Stotland } \\
\text { 12-item scale }{ }^{2}, \\
\text { self-report, } \\
\alpha=.55\end{array}$ & $\begin{array}{l}29 \text { yrs ( } n=122, M=33.17, S D=8.18) \text {, with } 30-42 \text { yrs in the } \\
\text { middle }(n=89, M=34.03, S D=6.70)(F=18.82, p<.0001) \text { Note: } \\
\text { higher scores = higher empathy. Empathy did not correlate } \\
\text { with age, marital status, education. Teenagers' empathy } \\
\text { correlated with competent maternal behaviour ( } r=.32 \text {, } \\
p<.05) \text {. }\end{array}$ & $\begin{array}{l}\text { defined, } \\
\text { unreliable } \\
\text { measure of } \\
\text { empathy, } \\
\text { unmatched } \\
\text { groups. }\end{array}$ \\
\hline
\end{tabular}




\begin{tabular}{|c|c|c|c|c|}
\hline $\begin{array}{c}\text { First author, } \\
\text { Empathy }\end{array}$ & $\begin{array}{c}\text { Time of } \\
\text { empathy } \\
\text { assessment }\end{array}$ & $\begin{array}{l}\text { Measure, } \\
\text { Method, } \\
\text { Reliability/ } \\
\text { Validity }\end{array}$ & Empathy findings & $\begin{array}{l}\text { Quality rating } \\
\qquad 0-5\end{array}$ \\
\hline $\begin{array}{l}\text { Graham (1993) } \\
\text { Cognitive \& } \\
\text { affective empathy }\end{array}$ & $\begin{array}{l}3 \mathrm{mths} \\
\text { postpartum }\end{array}$ & $\begin{array}{l}|\mathrm{RI}|^{3} \text { (total } \\
\text { score), } \\
28 \text {-item scale, } \\
\text { self-report, } \\
\alpha=.84\end{array}$ & $\begin{array}{l}\text { Mothers' empathy related to sensitivity to child cues ( } r=.65 \text {, } \\
p<.001) \text {. Accounted for } 42 \% \text { of variance to sensitivity } \\
(F=21.484, p<.0001) \text {. Mothers reported higher empathy } \\
(t=3.66, p<.001) \text { and more positive attitudes toward infant } \\
\text { care than fathers. }\end{array}$ & $\begin{array}{l}4 \text { - Empathy well } \\
\text { defined and } \\
\text { supported by } \\
\text { theory, validated } \\
\text { measure. }\end{array}$ \\
\hline $\begin{array}{l}\text { Zimerman (2003) } \\
\text { Cognitive \& } \\
\text { affective empathy }\end{array}$ & Pregnancy & $\begin{array}{l}\text { IRI, } \\
4 \text { 7-item } \\
\text { subscales, } \\
\text { self-report }\end{array}$ & $\begin{array}{l}\text { For women expecting after having a disabled child, Cognitive } \\
\text { empathy correlated with time spent in attachment mode } \\
\text { ( } r=.801, p<.001) \text {, i.e. thinking about, talking to, dreaming } \\
\text { about or trying to touch baby through the tummy. }\end{array}$ & $\begin{array}{l}1 \text { - Empathy not } \\
\text { defined, small } \\
\text { and specific } \\
\text { sample, validated } \\
\text { measure, unclear } \\
\text { analysis. }\end{array}$ \\
\hline
\end{tabular}




\begin{tabular}{|c|c|c|c|c|}
\hline $\begin{array}{l}\text { First author, } \\
\text { Empathy }\end{array}$ & $\begin{array}{c}\text { Time of } \\
\text { empathy } \\
\text { assessment }\end{array}$ & $\begin{array}{l}\text { Measure, } \\
\text { Method, } \\
\text { Reliability/ } \\
\text { Validity }\end{array}$ & Empathy findings & $\begin{array}{l}\text { Quality rating } \\
\qquad 0-5\end{array}$ \\
\hline $\begin{array}{l}\text { Kochanska (2004) } \\
\text { Cognitive empathy }\end{array}$ & $\begin{array}{l}7 \text { mths } \\
\text { postpartum }\end{array}$ & $\begin{array}{l}\text { IRI, } \\
\text { 7-item subscale, } \\
\text { self-report, } \\
\alpha=.79\end{array}$ & $\begin{array}{l}\text { Infants of empathic mothers showed more focused attention } \\
(r=.30, p<.01) \text { and less prone to anger }(r=.26, p<.05) \text {. } \\
\text { Mothers' cognitive empathy contributed to responsiveness } \\
\text { to child }(\theta=.23, p<.05) \text {, but not to shared positive ambience } \\
\text { or tracking. }\end{array}$ & $\begin{array}{l}2 \text { - Empathy not } \\
\text { defined, } \\
\text { unidimensional, } \\
\text { validated } \\
\text { measure. }\end{array}$ \\
\hline $\begin{array}{l}\text { Hodges (2010) } \\
\text { Cognitive \& } \\
\text { affective empathy, } \\
\text { personal distress }\end{array}$ & $\begin{array}{l}2-4 \text { mths } \\
\text { postpartum, } \\
\text { Pregnant } \\
\text { women: } 4-9 \\
\text { mths pregnant, } \\
\text { Non-mothers }\end{array}$ & $\begin{array}{l}\text { Batson 14-item } \\
\text { scale }{ }^{4} \text {, rated } \\
\text { emotions } \\
\text { following } \\
\text { viewing new } \\
\text { mother's } \\
\text { narrative, } \\
\text { Mind-reading } \\
\text { accuracy task }\end{array}$ & $\begin{array}{l}\text { Affective: Mothers' subjective empathy for another mother } \\
\text { was stronger than pregnant women }(F=6.76, p=.02) \text { or non- } \\
\text { mothers ( } F=32.06, p<.001) \text {. } \\
\text { Cognitive: Mothers no better than pregnant or non-mothers } \\
\text { at 'mind-reading', i.e. understanding the thoughts of another } \\
\text { mother. }\end{array}$ & $\begin{array}{l}3 \text { - Empathy } \\
\text { adequately } \\
\text { defined, non- } \\
\text { standardised } \\
\text { measures. }\end{array}$ \\
\hline
\end{tabular}




\begin{tabular}{|c|c|c|c|c|}
\hline $\begin{array}{c}\text { First author, } \\
\text { Empathy }\end{array}$ & $\begin{array}{l}\text { Time of } \\
\text { empathy } \\
\text { assessment }\end{array}$ & $\begin{array}{l}\text { Measure, } \\
\text { Method, } \\
\text { Reliability/ } \\
\text { Validity }\end{array}$ & Empathy findings & $\begin{array}{l}\text { Quality rating } \\
0-5\end{array}$ \\
\hline $\begin{array}{l}\text { Barr (2014) } \\
\text { Cognitive \& } \\
\text { affective empathy }\end{array}$ & $\begin{array}{l}0-6 \text { mths } \\
\text { postpartum }\end{array}$ & $\begin{array}{l}\text { IRI } \\
\text { (total and } \\
\text { subscale } \\
\text { scores), } 4 \text { × 7- } \\
\text { item subscales, } \\
\text { self-report }\end{array}$ & $\begin{array}{l}\text { For the cry group, no significant correlations between IRI and } \\
\text { mean frustration scores. Cognitive empathy ( } r=-.30, p=.04) \\
\text { and personal distress ( } r=.31, p=.03 \text { ) associated with higher } \\
\text { frustration. }\end{array}$ & $\begin{array}{l}3 \text { - Empathy not } \\
\text { defined, validated } \\
\text { measure. }\end{array}$ \\
\hline $\begin{array}{l}\text { Fairbrother (2015) } \\
\text { Cognitive \& } \\
\text { affective empathy }\end{array}$ & $\begin{array}{l}0-6 \text { mths } \\
\text { postpartum }\end{array}$ & $\begin{array}{l}\text { IRI, } \\
4 \times 7 \text {-item } \\
\text { subscales, } \\
\text { self-report }\end{array}$ & $\begin{array}{l}\text { Higher affective empathy predicted fewer harm thoughts } \\
\left(\chi^{2}=22.43, p<.001\right) \text {. Under stress, personal distress replaced } \\
\text { affective empathy as a predictor }\left(\chi^{2}=37.16, p<.001\right) \text {. }\end{array}$ & $\begin{array}{l}1 \text { - Empathy not } \\
\text { defined, validated } \\
\text { measure, pre- } \\
\text { existing group } \\
\text { differences. }\end{array}$ \\
\hline
\end{tabular}




\begin{tabular}{|c|c|c|c|c|}
\hline $\begin{array}{l}\text { First author, } \\
\text { Empathy }\end{array}$ & $\begin{array}{l}\text { Time of } \\
\text { empathy } \\
\text { assessment }\end{array}$ & $\begin{array}{l}\text { Measure, } \\
\text { Method, } \\
\text { Reliability/ } \\
\text { Validity }\end{array}$ & Empathy findings & $\begin{array}{l}\text { Quality rating } \\
\qquad-5\end{array}$ \\
\hline $\begin{array}{l}\text { Rajhans (2015) } \\
\text { Affective empathy }\end{array}$ & $\begin{array}{l}8 \mathrm{mths} \\
\text { postpartum }\end{array}$ & $\begin{array}{l}\text { IRI German } \\
\text { version, } \\
\text { 4-item subscale, } \\
\text { self-report }\end{array}$ & $\begin{array}{l}\text { More empathic mothers have infants more prone to respond } \\
\text { to others distress. In infants high on fearfulness, their } \\
\text { response to emotion was modulated by mothers' empathy } \\
(F=6.52, p=.019) \text {, i.e. infants of high empathy mothers show } \\
\text { low attention to fearful stimuli, low empathy mothers, high } \\
\text { attention. }\end{array}$ & $\begin{array}{l}3 \text { - Empathy } \\
\text { adequately } \\
\text { defined, } \\
\text { unidimensional, } \\
\text { validated } \\
\text { measure. }\end{array}$ \\
\hline $\begin{array}{l}\text { Sierau (2016) } \\
\text { Cognitive \& } \\
\text { affective empathy }\end{array}$ & $\begin{array}{l}\text { Baseline at } 36 \\
\text { wks pregnancy, } \\
\text { Time 2: } 24 \text { mths } \\
\text { postpartum }\end{array}$ & $\begin{array}{l}\text { IRI German } \\
\text { version, } \\
2 \text { 4-item } \\
\text { subscales, } \\
\text { self-report }\end{array}$ & $\begin{array}{l}\text { No improvement in empathy in mothers in home visit } \\
\text { program (time } 1: M=3.22, S D=0.03 \text {, time } 2: M=3.25, S D=0.03 \text { ) } \\
\text { or standard care: (time } 1: M=3.21, S D=0.03 \text {, time } 2: M=3.24 \text {, } \\
S D=0.03 \text { ). }\end{array}$ & $\begin{array}{l}2 \text { - Empathy not } \\
\text { defined, } \\
\text { multidimensional, } \\
\text { validated } \\
\text { measure, high } \\
\text { attrition. }\end{array}$ \\
\hline
\end{tabular}




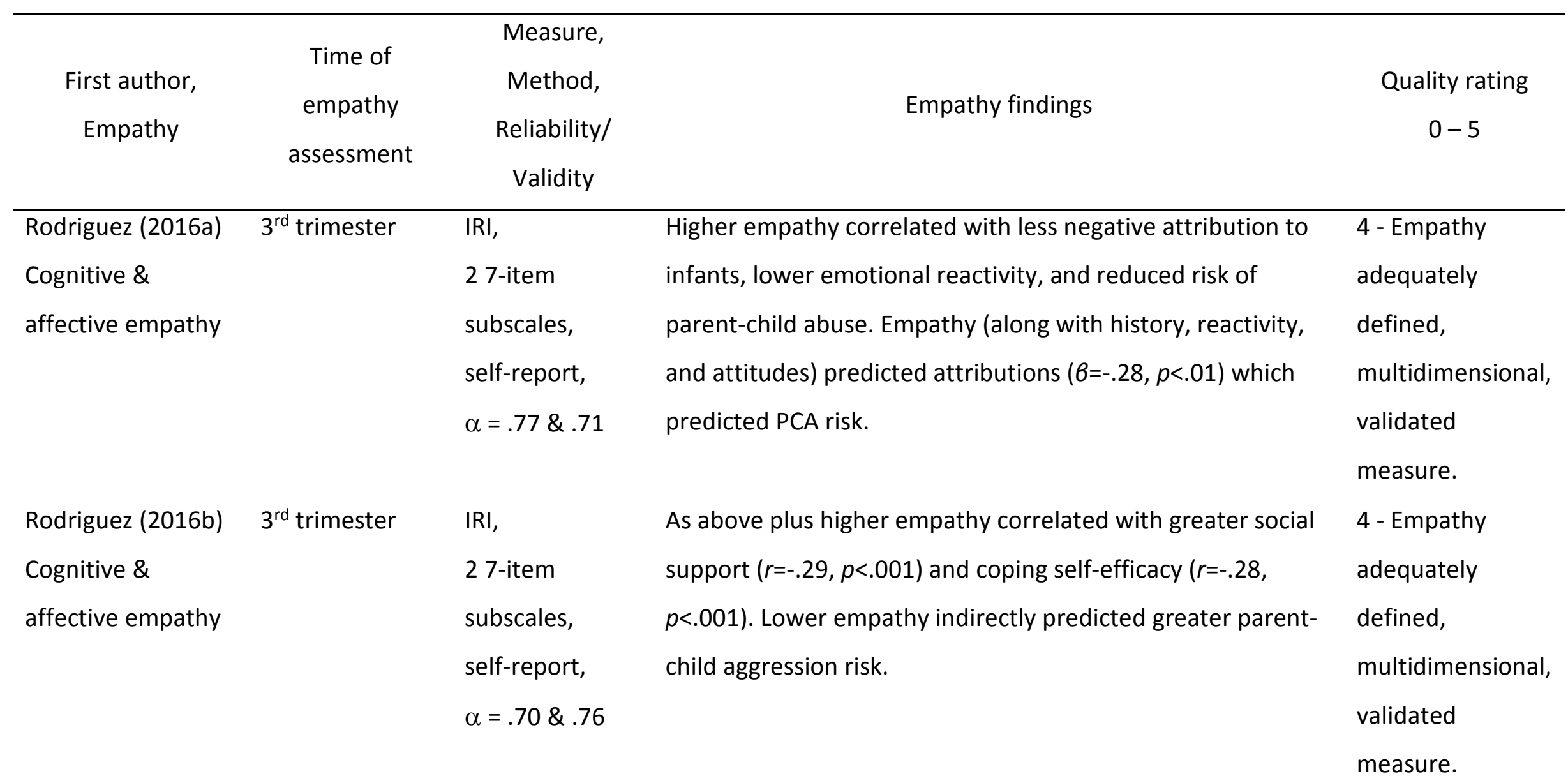




\begin{tabular}{|c|c|c|c|c|}
\hline $\begin{array}{c}\text { First author, } \\
\text { Empathy }\end{array}$ & $\begin{array}{c}\text { Time of } \\
\text { empathy } \\
\text { assessment }\end{array}$ & $\begin{array}{l}\text { Measure, } \\
\text { Method, } \\
\text { Reliability/ } \\
\text { Validity }\end{array}$ & Empathy findings & $\begin{array}{l}\text { Quality rating } \\
0-5\end{array}$ \\
\hline $\begin{array}{l}\text { Jia (2016) } \\
\text { Personal distress }\end{array}$ & $3^{\text {rd }}$ trimester & $\begin{array}{l}\text { IRI, } \\
\text { 7-item subscale, } \\
\text { self-report, } \\
\alpha=.77\end{array}$ & $\begin{array}{l}\text { Personal distress (PD) negatively correlated with time spent } \\
\text { caring for child (at } 3 \mathrm{mths}) \text {. Higher PD associated with lower } \\
\text { level of initial childcare }(B=-.07, p<.05) \text {, but increased over } \\
\text { time }(B=.07, p<.05) \text {. PD positively correlated with dysphoria } \\
\text { at } 3 \text { mths }(B=.15, p<.05) \text {, and anxiety at } 3 \text { mths }(B=.25, p<.05) \text {. }\end{array}$ & $\begin{array}{l}\text { 1-Empathy well- } \\
\text { defined, } \\
\text { unidimensional, } \\
\text { aversive aspect of } \\
\text { empathy, weak } \\
\text { inconsistent } \\
\text { findings. }\end{array}$ \\
\hline
\end{tabular}

Abbreviations: MEE, Measure of Emotional Empathy; IRI, Interpersonal Reactivity Index

${ }^{1}$ Mehrabian and Epstein (1972)

${ }^{2}$ Sherman and Stotland (1978)

${ }^{3}$ Davis (1983)

${ }^{4}$ Batson et al. (1996) 